\title{
REDAMAN SUARA PADA KOMPOSIT SANDWICH POLYESTER BERPENGUAT SERAT SISAL DENGAN CORE STYROFOAM
}

\author{
Sinarep*, Agus Dwi Catur*, M. Hafidzul** \\ ${ }^{*}$ Dosen Jurusan Teknik Mesin ${ }^{*}$ Mahasiswa Jurusan Teknik Mesin Universitas Mataram
}

\begin{abstract}
ABSTRAK
Penggunaan serat alam pada kulit komposit sandwich dalam sekat bangunan perlu diteliti kemampuannya untuk menyerap energi suara pada beberapa frekuensi suara target.

Bahan penelitian ini adalah serat sisal anyam, resin polyester, styrofoam. Komposit dibuat dengan metode hand lay-up. Komposit sandwich polyester tersusun dari dua skin dengan core ditengahnya. Fraksi volume serat komposit sandwich polyester sebagai skin adalah $30 \%$. Core yang digunakan ada 2 macam variasi ketebalan yaitu $30 \mathrm{~mm}$ dan $40 \mathrm{~mm}$. Spesimen dan prosedur pengujian koefisien redaman suara mengacu pada standar ASTM E1050.

Hasil rata-rata redaman suara yang besar terdapat pada spesimen komposit sandwich dengan ketebalan core $30 \mathrm{~mm}$ dengan hasil yang fluktuatif pada kenaikan tingkat frekuensi pegujian. Pada frekuensi rendah $250 \mathrm{~Hz}$ dengan nilai redaman 0,809 yang dilapisi kain beludru, frekuensi sedang $750 \mathrm{~Hz}$ dengan nilai redaman 0,819 yang dilapisi karpet, dan pada frekuensi tinggi $1500 \mathrm{~Hz}$ dengan nilai 0,725 yang dilapisi kain beludru.
\end{abstract}

Kata kunci : Koefisien redaman suara, styrofoam, komposit sandwich, core, skin.

\section{PENDAHULUAN}

Produk-produk komposit polimer yang diperjualbelikan pada saat ini, merupakan komposit yang terbuat dari serat sintesis (serat karbon dan gelas). Serat sintesis yang tidak lapuk dan tetap menjadi sampah, akan menjadi permasalahan lingkungan, karena tidak dapat terurai, dan menjadi limbah serat sintetis. Permasalahan limbah serat sintesis yang tidak ramah lingkungan, mendorong penggunaan serat alam diaplikasikan pada teknologi komposit yang ramah lingkungan.

Mengurangi noise di dalam sebuah konstruksi bangunan adalah penting di dalam desain dan pembuatannya. Beberapa metode dikaji untuk mengurangi noise dan sumber noise, salah satunya dengan mengunakan bahan penyerap suara atau bahan yang tidak meneruskan suara pada dinding, plafon, lantai, pintu. Suara diluar bangunan merambat dari sumber suara dengan media udara(airborne sound), dan lewat getaran struktur bangunan (structural sound). Treatment akustik untuk mengatasi structural sound adalah dengan pemasangan isolator dan damper [8] (Stein B, 2010)

Kebutuhan akan panel pelapis dinding untuk keperluan meredam bising dan meningkatkan kualitas bunyi dalam ruangruang studio pribadi kini terus meningkat. Namun, akses masyarakat pada panel semacam ini cukup rendah, disebabkan tingginya harga jual dan tidak meratanya ketersediaan di pasar [6](Mediastika, 2007).

Agar suara gaduh atau noise yang berasal dari dalam ruangan seperti peralatan elktronik, ruang sidang atau rapat dan lain sebagainya tidak diteruskan keluar ruangan atau dipantulkan keras di dalam ruangan maka pemasangan material yang mempunyai sifat isolator dan meredam mutlak dilakukan. Penggunaan serat alam yaitu serat sisal pada kulit komposit sandwich dengan matrik polyester dengan core berupa styrofoam pada penggunaan sekat bangunan perlu diteliti kemampuannya dalam menyerap energi suara pada beberapa frekuensi suara.

Dari sumber informasi dan uraian diatas mengindikasikan bahwa penelitian mengenai komposit sandwich dengan memadukan serat alam yaitu serat sisal dan styrofoam perlu dilakukan. Maka komposit sandwich akan diproduksi dan dikarakterisasikan, matrik polyester tak jenuh dipadukan dengan serat sisal sebagai penguat kulit komposit dan styrofoam sebagai inti komposit.

\section{Permasalahan}

Berdasarkan uraian diatas maka dapat dirumuskan permasalahan yang menjadi objek dalam penelitian ini yaitu bagaimana kualitas koefisien redaman suara dari bahan komposit sandwich polyester diperkuat serat sisal dengan styrofoam sebagai core. 
Adapun tujuan yang ingin dicapai dari penelitian ini adalah untuk mengetahui redaman suara pada komposit sandwich yang menggunakan serat sisal sebagai penguat dengan variasi ketebalan foam yang berbeda serta variasi pelapisan permukaan.

\section{STUDI PUSTAKA}

Salah satu penyerap bunyi memiliki tekstur yang berpori, lembut ataupun kasar misal karpet dan kain beludru. Manusia pun dapat dikatakan penyerap bunyi, jika gelombang bunyi menumbuk manusia. Menurut definisi, penyerapan bunyi adalah perubahan energi bunyi menjadi suatu bentuk lain, biasanya panas, ketika melewati suatu bahan atau ketika menumbuk suatu permukaan [5](Kentut, 2006). Koefisien serap bunyi biasanya dinotasikan dengan $\alpha$, mempunyai nilai antara 0 sampai 1,0 . Koefisien serap bunyi bergantung secara dinamis pada frekuensi bunyi dan sudut yang dibentuk oleh gelombang bunyi yang datang terhadap garis normal permukaan medium.

Nilai koefisien penyerapan bunyi pada suatu frekuensi tertentu, seperti yang ada dalam keputusan akustik arsitektur, diratarata terhadap semua sudut datang pada suatu frekuensi tertentu (dating acak). Standar dibuat untuk membuat daftar koefisien penyerapan bunyi pada frekuensi standar yang meliputi bagian yang paling penting dari jangkauan frekuensi audio, yaitu pada frekuensi 250, 500, 1000, 2000, $4000 \mathrm{~Hz}$ [7] (Mufida Sari, 2009).

Panel pelapis yang terbuat dari bahan baku dengan harga rendah diperkirakan dapat menurunkan harga jual barang dimaksud. Telah diselidiki kemungkinan penggunaan limbah sebagai bahan baku panel. Adapun limbah yang dipilih adalah jerami padi, mengingat material ini memiliki karakteristik sebagaimana bahan-bahan untuk keperluan akustik, seperti elastisitas cukup tinggi dan mengandung rongga udara. Hasilnya menunjukkan bahwa jerami pada jenis IR sangat potensial digunakan sebagai bahan baku panel [6](Mediastika, 2007).

\section{Komposit sandwich}

Komposit sandwich merupakan komposit yang tersusun dari 3 lapisan yang terdiri dari flat composit dan atau metal sheet sebagai skin serta core di bagian tengahnya (gambar 1). Komposit sandwich di buat dengan tujuan untuk efisiensi berat yang optimal, namun mempunyai kekuatan yang tinggi. Sehingga untuk mendapatkan karakteristik tersebut, pada bagian tengah di antara kedua skin dipasang core.

Komposit sandwich umum diterapkan pada komposit matrik polymer adalah konsep struktur panel yang terdiri dari dua laminat paralel tipis mengapit core yang ringan. Konstruksi sandwich dipilih ketika diharapkan struktur mempunyai kekakuan tinggi dengan berat yang relatif lebih ringan dibandingkan komposit laminat monolit [1](Anonim,2002).

COR E

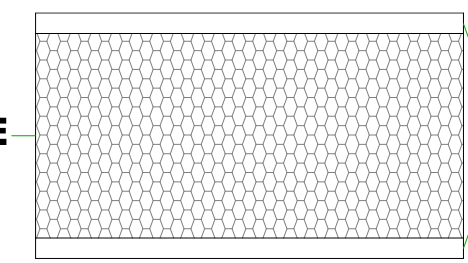

S K I N

Gambar1 Struktur komposit sandwich

\section{Komposit Serat Anyam (Woven Fiber Composite)}

Komposit ini tidak mudah terpengaruh pemisahan antar lapisan karena susunan seratnya juga mengikat antar lapisan. Akan tetapi susunan serat memanjangnya yang tidak begitu lurus mengakibatkan kekuatan dan kekakuan tidak sebaik tipe continuous fiber.

\section{Material Pengikat Komposit (Matrik)}

Material pengikat disebut juga matrik. Jenis matrik yang digunakan berupa polimer, keramik atau metalik. Jenis matrik yang digunakan dalam sistem komposit menunjukkan nama dari komposit tersebut. Contoh: Komposit Matrik Polimer (KMP), Komposit Matrik Keramik (KMK), Komposit Matrik Logam (KML).

Material pengikat ini pada sistem komposit berfungsi sebagai penerus beban kepada material penguat (fiber), untuk memisahkan fiber yang satu dengan yang lainnya serta menghambat penjalaran retak yang timbul dari perpatahan fiber.

Dua hal yang perlu diperhatikan dalam pembentukan sistem komposit agar didapat produk yang efektif, yaitu : komponen penguat harus memiliki modulus elastisitas yang lebih tinggi daripada komponen matriknya dan harus ada ikatan permukaan yang kuat antara ikatan komponen penguat dengan matriknya. 


\section{Styrofoam}

Salah satu bagian terpenting dari sandwich adalah core, dimana bagian ini harus cukup kaku agar jarak antar permukaan terjaga. Dengan kekakuannya, core harus mampu menahan geseran agar tidak terjadi slide antar permukaan. Bahan dengan tingkat kekakuan yang rendah tidak baik untuk core, karena kekakuan pada sandwich akan berkurang atau hilang. Tidak hanya kuat dan mempunyai densitas rendah, core biasanya mempunyai syarat lain, seperti tingkat kadar air, buckling, umur panjang (age resistance), dan lain sebagainya.

Foam adalah salah satu material yang umum digunakan sebagai core. Foam dapat dihasilkan dari polimer buatan yang mencakup polyvinyl chloride (PVC), karet sintesis/polystyrene (PS), polyurethane (PU), polymethyl methacrylamide (acrylic), polyetherimide (PEI) dan styreneacrylonitrile $(S A N)$. Densitas rata-rata dari bahan tersebut kurang lebih $30 \mathrm{~kg} / \mathrm{m}^{3}-300 \mathrm{~kg} / \mathrm{m}^{3}$. [2](Anonim,2009).

Bahan dasar styrofoam adalah polystyrene, suatu jenis plastik yang sangat ringan, kaku, tembus cahaya, dan murah. Namun, bahan tersebut cepat rapuh. Karena kelemahannya tersebut, polystyrene dicampur senyawa butadin. $\mathrm{Hal}$ ini menyebabkan polystyrene kehilangan sifat jernihnya dan berubah warna menjadi putih susu. Kemudian untuk kelenturannya, ditambahkan zat plasticier seperti dioktilptalat (DOP), butyl hidroksi toluene, dan butyl stearat [2](Anonim, 2009).

\section{Absorpsi Suara}

Ketika energi suara mengenai material, sebagian suara yang mengenai permukaan material akan dipantulkan dan sebagian diserap oleh material, tetapi perlu di ingat bahwa tidak ada material yang sempurna dalam memantulkan maupun meredam suara. Istilah yang umum digunakan untuk mendifinisikan karakteristik peredaman suara yang biasa dilambangkan dengan $(\alpha)$ dirumuskan sebagai berikut:

$$
\alpha=1-\frac{n-1}{n+1} \times \frac{n-1}{n+1}
$$

Dimana :

$$
\begin{aligned}
n= & \text { Perbandingan tekanan suara } \\
& \text { maksimal terhadap tekanan } \\
& \text { suara minimal. } \\
\alpha= & \text { Koefisien redaman suara. }
\end{aligned}
$$

Untuk menentukan nilai $n$ harus di ketahui terlebih dahulu nilai tekanan suara maximum (Pmax), tekanan suara minimum (Pmin). Persamaannya adalah sebagai berikut :

$$
n=\frac{P \max \times \text { skala } m V}{P \min \times \text { skala } m V}
$$

\section{Dimana :}

$$
\begin{aligned}
& \text { Pmax }=\text { Tekanan suara maksimal } \\
& \text { Pmin }=\text { Tekanan suara minimal }
\end{aligned}
$$

Koefisien redam suara tergantung dari material, koefisien redaman 1.0 dianggap merupakan penyerapan yang $100 \%$ dengan pemantulan energi suara tidak ada. Dengan demikian kita dapat simpulkan bahwa tidak ada material yang sempurna dalam penyerapan suara.

Pada suatu ruangan dengan sumber suara di dalamnya, ketika gelombang suara menyentuh dinding atau langit-langit, sebagian kecil ditransmisikan, sebagian kecil diserap, dan sebagian suara dipantulkan. Proporsi yang tepat jelas tergantung pada sifat konstruksi. Ketika desain ruang akustik diterapkan pada permukaan ruangan, beberapa energi dalam gelombang suara dihilangkan sebelum suara mencapai dinding.

Sebagaimana dilaporkan (Mediastika, 2008), untuk ruang-ruang dengan besaran $30 \mathrm{~m}^{3}$ sampai dengan $90 \mathrm{~m}^{3}$ seperti dimiliki bangunan-bangunan pribadi yang kemudian dialih fungsikan sebagai bioskop pribadi (home theatre), maka untuk memiliki kualitas waktu dengung dibawah 1 detik diperlukan koefisien serap minimal 0,22 (koefisien serap pada volume maksimum: $\left.90 \mathrm{~m}^{3}\right)$. Suatu material disebut menyerap suara dengan baik, bila kemampuan serapnya diatas 0,2 [4] (Egan, 1972).

\section{METODE PENELITIAN}

Penelitian diawali dengan pengambilan serat dari tanaman sumber serat daun. Serat sisal diambil dari daun tanaman nanas Bali (agave sisalana weberı) yang sudah dewasa ditandai dengan warna hijau tua pada daun. Keseragaman serat perlu dijaga dengan mengambil daun yang mempunyai panjang mendekati sama. Daun kemudian digesek dengan pisau tajam agar lapisan palisade tissue tempat klorofil, epidermis dan lapisan cuticula hilang. 
Daun yang sudah bersih akan tampak serat-seratnya yang berwarna putih kekuningan. Agar seratnya dapat diambil dengan mudah daun direndam kedalam air selama dua hari. Serat dipisahkan dari daging daun dengan menyisir daun menggunakan sikat kawat berulang-ulang sampai diperoleh serat yang bersih. Serat kemudian dikeringkan dibawah sinar matahari selama satu hari.

\section{Pembuatan kulit komposit sandwich}

Pembuatan skin komposit dilakukan dengan metode cetak tangan (hand ly up). Langkah awal adalah mengoleskan pengkilap porselin (MAA) dan dikeringkan, ini bertujuan untuk mempermudah pengangkatan kulit komposit dari cetakan pada saat sudah kering. Resin polyester dicampur dengan $2 \%$ hardener (metil etil keton) agar waktu curing lebih cepat. Resin polyester dan serat ditimbang untuk variasi perbandingan matrik penguat sebesar 30\% untuk serat. Sebagian resin yang telah tercampur dituangkan ke dalam cetakan dan diratakan. Serat yang dianyam tegak lurus dimasukkan dalam cetakan, dibenamkan dalam resin kemudian diratakan lagi. Kemudian cetakan ditutup dan ditekan dengan menggunakan klem, pengkleman harus dilakukan secara bersamaan agar penekanannya merata penekanan ini bertujuan untuk mendapatkan ketebalan spesimen yang diinginkan. Setelah itu cetakan yang sudah berisi resin dan serat tersebut didiamkan selama 24 jam, setelah kering spesimen dibuka dan diangkat dari dalam cetakan dan dipotong sesuai dengan ukuran yang dibutuhkan.

\section{Preparasi Komposit Sandwich}

Konstruksi komposit sandwich terdiri dari core berupa styrofoam dan kulit komposit sandwich yang terdiri dari dua laminat yang mengapitnya. Pada pembuatan komposit sandwich ini antara core dan kulit direkatkan dengan perekat epoxy. Styrofoam yang dipakai mempunyai ketebalan divariasikan masing-masing 30 $\mathrm{mm}$ dan $40 \mathrm{~mm}$.

Komposit dibiarkan memadat dan menyatu (curing) antara kulit dan core didalam ruangan selama 6 jam, untuk menyempurnakan proses pemadatan maka komposit dicuring didalam oven pemanas pada suhu $80^{\circ} \mathrm{C}$ selama 3 jam. Komposit sandwich dikeluarkan dari oven dan setelah dingin dipotong dengan gergaji untuk membuat spesimen uji.

\section{Karakterisasi Sifat Komposit sandwich}

Komposit dibuat dengan variabelvariabel produksi yang berbeda sehingga diperoleh 6 jenis komposit yang berbeda yaitu:

1. Komposit sandwich berpenguat serat sisal menggunakan matrik polyester dengan ketebalan core styrofoam $30 \mathrm{~mm}$ dan tidak dilapisi.

2. Komposit sandwich berpenguat serat sisal menggunakan matrik polyester dengan ketebalan core styrofoam $30 \mathrm{~mm}$ dan dilapisi kain beludru.

3. Komposit sandwich berpenguat serat sisal menggunakan matrik polyester dengan ketebalan core styrofoam $30 \mathrm{~mm}$ dan dilapisi karpet.

4. Komposit sandwich berpenguat serat sisal menggunakan matrik polyester dengan ketebalan core styrofoam $40 \mathrm{~mm}$ dan tidak dilapisi.

5. Komposit sandwich berpenguat serat sisal menggunakan matrik polyester dengan ketebalan core styrofoam $40 \mathrm{~mm}$ dan dilapisi kain beludru.

6. Komposit sandwich berpenguat serat sisal menggunakan matrik polyester dengan ketebalan core styrofoam $40 \mathrm{~mm}$ dan dilapisi karpet.

Jika tiap uji dilakukan pengulangan tiga kali maka untuk semua jenis/varian komposit dilakukan sebanyak 18 pengujian.

Uji untuk memperoleh absorbtion coefficient dilakukan pada frekuensi suara target $250 \mathrm{~Hz}, 500 \mathrm{~Hz}, 750, \mathrm{HZ}, 1000 \mathrm{~Hz}$, $1250 \mathrm{HZ}, 1500 \mathrm{HZ}$. Pada uji absorbtion coefficient ini komposit dilakukan variasi pelapisan skin, 2 ketebalan styrofoam.

Pengukuran performa penyerapan suara oleh komposit dilakukan dengan standar uji ASTM E-1050 dengan ukuran spesimen diameter $99 \mathrm{~mm}$ menggunakan sebuah tabung impedance medium berdiameter $10 \mathrm{~cm}$, dua mikrofon dan peralatan analisis frekuensi digital. Sebuah sumber suara (loudspeaker) diletakan pada satu sisi tabung dan spesimen komposit diletakkan pada sisi tabung yang lain. 


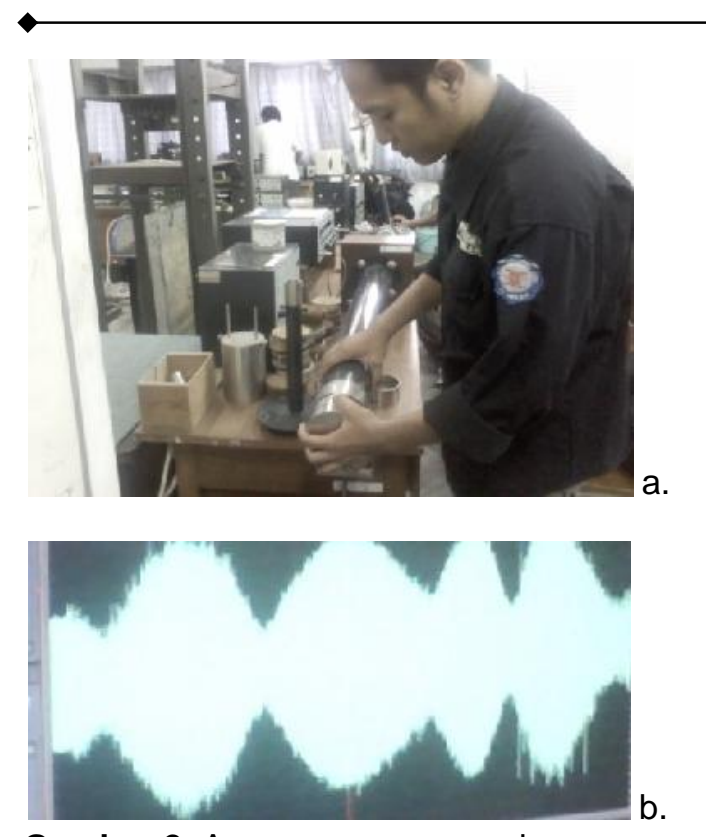

Gambar 2. A pemasangan spesimen

b. tekanan suara tercatat meter saat pengujian koefisien serap panel.

\section{Proses pengujian akustik}

1) Siapkan alat dan bahan pengujian yaitu spesimen dan alat pengujian akustik.

2) Merangkai kabel-kabel penghubung pada peralatan pengujian, pastikan semua terpasang dengan kuat dan benar.

3) Menyalakan alat.

4) Mengatur frekuensi pada generator pada frekuensi terendah penelitian yaitu 250 $\mathrm{Hz}$.

5) Menempatkan spesimen pada salah satu ujung tabung impedansi yaitu pada spesimen holder.

6) Mencatat nilai tekanan maksimum dan tekanan minimum yang terbaca di layar komputer serta posisi microphone yang terlihat pada mistar.

7) Menghitung nilai koefisien penyerapan suara dari data yang diperoleh.

\footnotetext{
Prinsip kerja alat ukur koefisien penyerapan suara adalah suara dibangkitkan oleh generator, kemudian suara dikirimkan ke loudspeaker yang akan disalurkan melalui tabung sampai ke permukaan spesimen. Setelah suara menyentuh permukaan spesimen sebagian suara akan diserap dan sebagian akan dipantulkan. Sebagian suara yang dipantulkan akan menyentuh microphone probbe yang berada didalam tabung impedansi kemudian masuk ke microphone dan dikuatkan oleh amplifier. Sebelum ke meter, suara akan di filter, di meter akan terbaca nilai tekanan suara maksimum dan
}

tekanan suara minimum yang digunakan untuk memperoleh nilai koefisien penyerapan suara.

\section{HASIL DAN PEMBAHASAN}

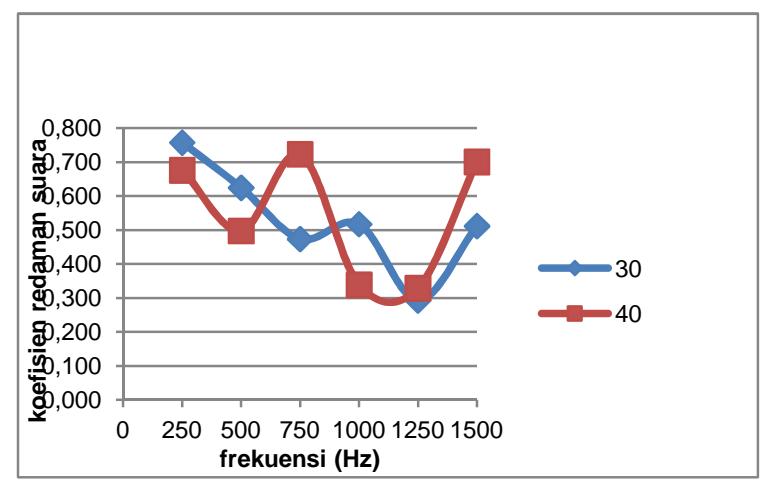

Gambar 3 Grafik koefisien redaman suara komposit sandwich tebal core styrofoam $30 \mathrm{~mm}$ dan $40 \mathrm{~mm}$ tanpa dilapisi.

Ket : 30 : spesimen komposit sandwich polyester dengan tebal core styrofoam $30 \mathrm{~mm}$ dan tidak dilapisi.

40 : spesimen komposit sandwich polyester dengan tebal core styrofoam $40 \mathrm{~mm}$ dan tidak dilapisi.

Dari gambar 3 diatas, menunjukkan lebih besar nilai rata-rata koefisien redaman suara pada frekuensi rendah dan sedang untuk spesimen dengan tebal $30 \mathrm{~mm}$ dibandingkan spesimen dengan tebal 40 $\mathrm{mm}$. Pada frekuensi tinggi lebih besar nilai rata-rata spesimen tebal $40 \mathrm{~mm}$ dibandingkan dengan spesimen tebal 30 $\mathrm{mm}$. Tetapi hal ini tidak sesuai dengan pernyataan [3] Doelle (1972), yang mengatakan bahwa efisiensi akustik bahan peredam berpori membaik pada jangkauan frekuensi rendah dengan bertambahnya ketebalan, karena nilai hasil koefisien redaman suara yang diuji pada penelitian ini menunjukkan nilai yang lebih besar spesimen dengan ketebalan core $30 \mathrm{~mm}$ dibandingkan dengan tebal $40 \mathrm{~mm}$. Jika dilihat dari frekuensi yang menjadi acuan yaitu $500 \mathrm{~Hz}$, nilai hasil rata-rata koefisien redaman suara sebesar 0,628 untuk tebal $30 \mathrm{~mm}$ dan 0,574 untuk tebal $40 \mathrm{~mm}$. Walaupun pada frekuensi tinggi sesuai dengan pernyataan Doelle, yang jika ketebalannya ditambah, maka penyerapannya akan naik. Hal ini terlihat pada frekuensi $1500 \mathrm{~Hz}$ dengan nilai 0,512 
dengan tebal $30 \mathrm{~mm}$ dan 0,710 dengan tebal $40 \mathrm{~mm}$. Hal ini dikarenakan susunan komposit sandwich pada penelitian ini menggunakan core styrofoam, dimana styrofoam memiliki massa yang rendah, sehingga pada frekuensi rendah hasil ratarata koefisien redaman suara lebih besar pada ketebalan $30 \mathrm{~mm}$ dibandingkan 40 $\mathrm{mm}$, dan pada frekuensi tinggi hasil koefisien redaman suara lebih besar nilai koefisien redaman suara pada spesimen dengan ketebalan $40 \mathrm{~mm}$. Komposisi pada spesimen yang tidak dilapisi sama pada setiap variasi, hanya saja bentuk anyaman pada spesimen dengan tebal $30 \mathrm{~mm}$ sedikit berubah bentuk dan tidak lurus dibandingkan spesimen dengan ketebalan $40 \mathrm{~mm}$, dikarenakan proses pencetakan dengan teknik hand lay-up. Sehingga nilai koefisien redaman suara pada ketebalan 30 $\mathrm{mm}$ menurun dari frekuensi rendah sampai frekuensi sedang.

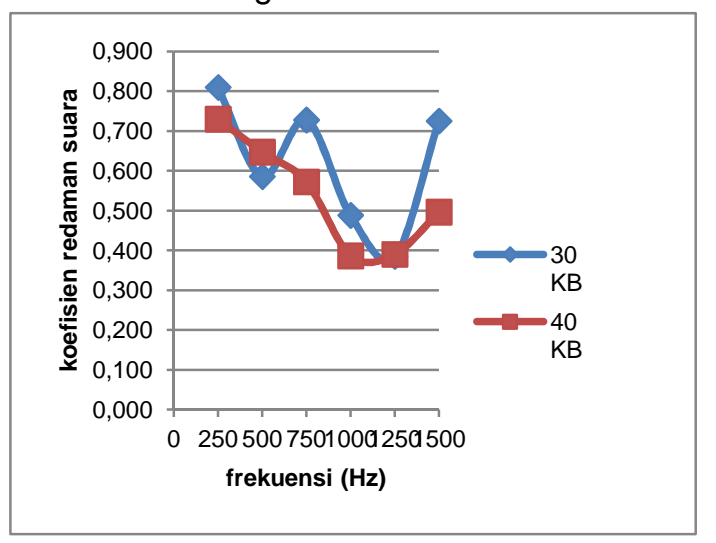

Gambar 4 Grafik koefisien redaman suara pada spesimen yang tebalnya $30 \mathrm{~mm}$ dan $40 \mathrm{~mm}$ dilapisi kain beludru.

Keterangan:

$30 \mathrm{~KB}$ : spesimen komposit sandwich polyester dengan tebal core styrofoam $30 \mathrm{~mm}$ dan dilapisi kain beludru.

$40 \mathrm{~KB}$ : spesimen komposit sandwich polyester dengan tebal core styrofoam $40 \mathrm{~mm}$ dan dilapisi kain beludru.

Dari gambar 4, nilai rata-rata koefisien redaman suara spesimen dengan variasi ketebalan $30 \mathrm{~mm}$ dan $40 \mathrm{~mm}$ yang dilapisi kain beludru, penyerapan lebih besar pada spesimen dengan tebal $30 \mathrm{~mm}$ pada frequensi $750 \mathrm{~Hz}$. Dapat dikatakan, hal ini juga tidak sesuai dengan pernyataan sebelumnya, walaupun untuk frekuensi yang menjadi acuan yaitu $500 \mathrm{~Hz}$, lebih besar koefisien redaman suara pada spesimen dengan ketebalan $40 \mathrm{~mm}$ sebesar 0,647 sedangkan spesimen dengan tebal $30 \mathrm{~mm}$ sebesar 0,586. Hal ini dikarenakan gelombang suara yang datang pertama kali diterima oleh kain beludru, dimana kain beludru memiliki permukaan yang halus dengan pori-pori yang rapat, kemudian gelombang energi suara diteruskan pada gabungan serat sisal dengan polyester.

Pada komposit sandwich perpaduan antara polyester dan serat sisal, memiliki komposis yang sama, hanya saja terdapat sedikit void pada spesimen dengan ketebalan $40 \mathrm{~mm}$ serta perlakuan pada skin yang dilubangi berbeda, karena pelubangan pada spesimen dengan ketebalan $30 \mathrm{~mm}$ dominan pada polyester saja, sedangkan pada spesimen $40 \mathrm{~mm}$ pelubangan skin dominan pada serat sisal dengan polyester. Gelombang energi suara yang melewati komposit sandwich pada ketebalan $30 \mathrm{~mm}$, dominan diterima oleh perpaduan serat sisal dan polyester, komposit tersebut yang menyebabkan gelombang energi suara yang akan diteruskan ke styrofoam rendah, sehingga nilai rata-rata koefisien redaman suara lebih besar hampir disetiap kenaikan frekuensi. Setelah itu gelombang suara bergetar pada styrofoam. Hal ini pula yang menyebabkan hasil koefisien redaman suara lebih besar pada frekuensi tinggi dengan spesimen ketebalan $30 \mathrm{~mm}(0,725)$ dibandingkan dengan ketebalan $40 \mathrm{~mm}$ $(0,496)$.

Dari gambar 5, kemampuan redaman spesimen yang dilapisi karpet dari frekuensi sedang sampai menengah, lebih besar nilai koefisien redaman suara pada spesimen dengan ketebalan $30 \mathrm{~mm}$ dibandingkan dengan ketebalan $40 \mathrm{~mm}$.

Seiring naiknya frekuensi, terjadi peningkatan redaman suara pada spesimen dengan ketebalan $40 \mathrm{~mm}$ dibandingkan spesimen dengan ketebalan $30 \mathrm{~mm}$. Hal ini dikarenakan gelombang suara yang datang pertama kali diterima oleh karpet, dimana karpet sendiri mempunyai permukaan yang kasar serta pori-pori yang rapat, sehingga gelombang suara yang datang pertama kali bergetar pada karpet. Setelah itu suara diterima oleh gabungan polyesterdengan serat sisal, dimana serat sisal memiliki massa jenis yang rendah dan memiliki kemampuan yang baik untuk redaman suara, setelah itu gelombang suara diteruskan sampai diterima core styrofoam. 


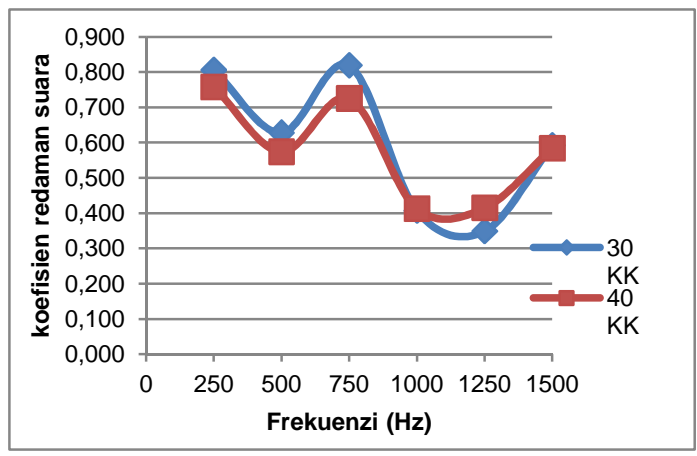

Gambar 5 Grafik koefisien redaman suara pada spesimen yang tebalnya $30 \mathrm{~mm}$ dan $40 \mathrm{~mm}$ dilapisi karpet.

Keterangan :

$30 \mathrm{KK}$ : spesimen komposit sandwich polyester dengan tebal core styrofoam $30 \mathrm{~mm}$ dan dilapisi karpet.

$40 \mathrm{KK}$ : spesimen komposit sandwich polyester dengan tebal core styrofoam $40 \mathrm{~mm}$ dan dilapisi karpet. bahan komposit yang dilapisi karpet, karena spesimen yang dilapisi karpet mendapatkan nilai rata-rata koefisien redaman suara yang tinggi, hal ini dipengaruhi oleh kekasaran permukaan karpet serta pori-pori karpet itu sendiri. Berbeda dengan permukaan yang tidak dilapisi, karena permukaannya yang licin dan halus serta tidak memiliki pori-pori. Sedangkan pada kain beludru, permukaan cukup halus dan pori-pori cukup rapat.

Komposisi sandwich perpaduan serat sisal dan polyester harus homogen dan tidak ada void, karena hal itu sangat mempengaruhi setiap proses redaman suara.

Demikian pula pelapisan permukaan skin komposit sandwich, cukup berpengaruh pada nilai koefisien redaman suara pada hampir tingkatan frekuensi, baik itu frekuensi rendah, frekuensi sedang dan frekuensi tinggi.

Untuk nilai koefisien redaman suara pada frekuensi rendah, lebih baik memilih spesimen yang dilapisi kain beludru, hal ini disebabkan permukaan skin yang halus dan

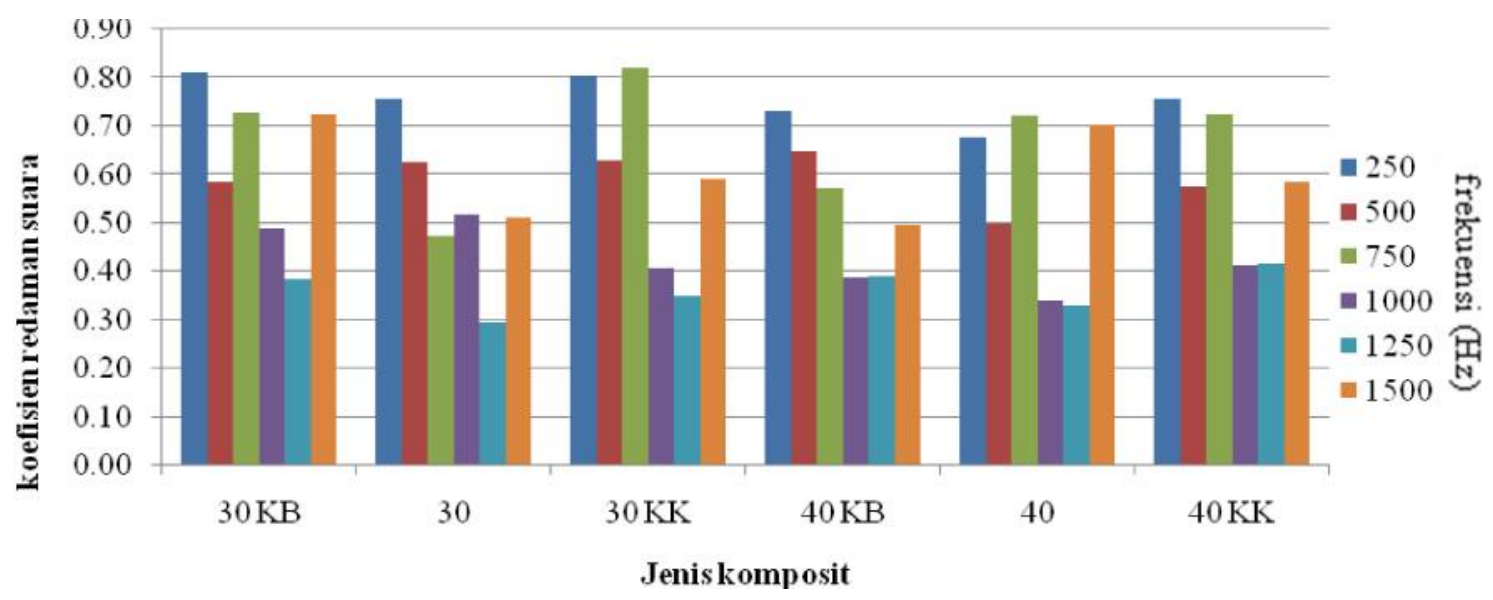

Gambar 6 Grafik koefisien redaman suara terhadap variasi jenis komposit.

Pada spesimen yang dilapisi karpet, komposisi komposit sandwich sama. Tetapi dalam hal ini, hasil rata-rata koefisien redaman suara dengan ketebalan $30 \mathrm{~mm}$ mendominasi pada hampir setiap kenaikan frekuensi, walupun spesimen dengan ketebalan $40 \mathrm{~mm}$ merangkak naik pada frekuensi sedang, hal ini dikarenakan lapisan skin yang dilapisi karpet.

Dari gambar 6, dapat dilihat hasil koefisien redaman suara tertinggi terdapat pada jenis komposit dengan ketebalan 30 $\mathrm{mm}$ serta dilapisi karpet pada frekuensi 750 $\mathrm{Hz}$.

Untuk mendapatkan koefisien redaman yang bagus, lebih baik memilih lunak dari jenis bahan kain beludru. Bila menginginkan redaman suara yang baik untuk frekuensi sedang, didapat spesimen yang dilapisi karpet, hal ini disebabkan permukaan karpet yang kasar. Pada frekuensi tinggi, lebih baik memilih spesimen dengan spesimen yang dilapisi kain beludru.

Pelapisan permukaan skin tidak berpengaruh pada frekuensi tinggi yaitu $1500 \mathrm{~Hz}$, karena nilai koefisien redaman suara spesimen yang tidak dilapisi sebesar 0,701 , untuk yang dilapisi berada dibawahnya, dengan nilai masing-masing yang dilapisi karpet sebesar 0,584 dan yang dilapisi kain beludru sebesar 0,496. Sehingga, pelapisan permuakaan skin pada 
komposit sandwich polyester cukup mempengaruhi nilai koefisien redaman suara, terutama pada frekuensi sedang antara frekuensi $750-1250 \mathrm{~Hz}$.

Jika ingin mendapatkan koefisien redaman suara yang bagus untuk frekuensi rendah, lebih baik menggunakan spesimen dengan ketebalan core $30 \mathrm{~mm}$ yang dilapisi kain beludru. Bila ingin mendapatkan nilai koefisien redaman suara pada frekuensi menengah, lebih baik memilih spesimen dengan ketebalan core $30 \mathrm{~mm}$ yang dilapisi kain karpet. Spesimen dengan ketebalan core $30 \mathrm{~mm}$ yang dilapisi kain beludru, baik digunakan pada frekuensi tinggi.

\section{Kesimpulan}

Dari hasil pengujian dan pembahasan yang telah dilakukan, maka dapat ditarik beberapa kesimpulan sebagai berikut :

1. Komposisi yang paling ideal sebagai peredam suara adalah gabungan antara skin polyester dan serat sisal dengan ketebalan core $30 \mathrm{~mm}$ serta pelapisan karpet, dengan nilai koefisien redaman suara 0,819 .

2. Kisaran kemampuan hasil rata-rata redaman suara secara keseluruhan berkisar antara 0,293-0,819, tidak terjadi perubahan yang mencolok pada nilai rata-rata koefisien redaman suara dengan adanya varisai ketebalan core.

3. Nilai rata-rata koefisien redaman suara dengan permukaan skin yang dilapisi karpet lebih besar dibandingkan dengan yang tidak dilapisi ataupun yang dilapisi kain beludru, terutama pada frekuensi sedang antara frekuensi $750-1250 \mathrm{~Hz}$.

\section{DAFTAR PUSTAKA}

[1] Anonim, 2002, Composite Material Handbook, Volume 3: Polymer Matrix Composite, material usage, design and analysis, Department of defence, USA.

[2] Anonim, 2009, "Styrofoam", http://oryzawisesa.wordpress.com/

[3] Doelle, L.L., 1993, Akustik Lingkungan (terjemahan Lea Prasetyo). Jakarta. Erlangga.

[4] Egan, M.D., 1972, Concepts in Architectural Acoustic, PrenticeHall Inc., New Jersey, hal. 91-93.

[5] Kentut, S., 2006, Analisis pengaruh kolom udara terhadap nilai koefisien serap bunyi pada dinding partisi menggunakan metode tabung impedansi dua microfon, Skripsi, Univ. Sebelas Maret, Surkarta.

[6] Mediastika, C. E., 2008, Kualitas Akustik Panel Dinding Berbahan Baku Jerami, Journal of Architectur and Built Environment, Vol. 36, No. 2, 127-134 ISSN 0126-219X.

[7] Mufida Sari, W. F., 2009, Simulasi Reverberation Time Sound System Efektif Pada Bangunan Gedung Sc Universitas Islam Negeri Maulana Malik Ibrahim Malang, Skripsi, Univ. Maulana Malik Ibrahim, Malang.

[8] Stein, B., Grondzik, W. T., Kwok, A. G., Reynolds, J. S., 2010, Mechanical \& Electrical Equipment for Buildings, Wiley \& Sons, Inc., Michigan. 